\title{
KEPEMILIKAN HAK ATAS TANAH DALAM PERKAWINAN CAMPURAN*
}

\author{
Justitia Henryanto Ghazaly \\ Fakultas Hukum, Universitas Surabaya \\ email: justitia_achie@yahoo.com
}

\begin{abstract}
The legal consequences of the resident in particular the mixed marriage which the parties get impediment to perform legal acts primarily to have the right to land due to the occurrence of rounding of the property along with foreign nationals where the regulations Legislation on land in Indonesia adhering to the principles of nationalism. The parties in the mixed marriage must make an agreement to marry a treasure at the time or before the marriage is held as it is mentioned in article 29 of the Marriage Act (UUP). The issue arises for mixed marriage parties that do not yet have a mating agreement in which legal protection for Warga-negara Indonesia maintains Kewarga-negaraannya is very noted. In writing this author uses a research method of normative juridical approaches which are sourced from secondary legal substances by understanding the law as a regulatory device or a positive norm in the prevailing legislation. However, after the decision of the MK No. 69 The law of marriage had a change especially concerning the marriage agreement in which the marriage agreement could be made during the wedding, which also applies to third parties during the agreement to be registered/According to the prevailing laws and regulations.
\end{abstract}

Keywords: Mixed Marriages; Marriage Agreements; Third Parties.

\begin{abstract}
Abstrak
Akibat hukum dari perkawinan khususnya perkawinan campuran yang mana para pihak mendapat halangan untuk melakukan perbuatan hukum terutama untuk memiliki hak atas tanah dikarenakan terjadinya pembulatan harta bersama dengan warga Negara asing dimana peraturan perundang-undangan mengenai pertanahan di Indonesia menganut asas Nasionalisme. Para pihak dalam perkawinan campuran harus membuat perjanjian kawin pisah harta pada waktu atau sebelum perkawinan dilangsungkan seperti mana yang di sebutkan dalam pasal 29 Undang-Undang Perkawinan (UUP). Persoalan di sini timbul bagi para pihak perkawinan campuran yang belum memiliki perjanjian kawin di mana perlindungan hukum bagi Warga-negara Indonesia yang mempertahankan kewarga-negaraannya sangat di perhatikan. Dalam penulisan ini penulis menggunakan metode penelitian pendekatan yuridis normatif dimana bersumber dari bahan-bahan hukum sekunder dengan memahami hukum sebagai perangkat peraturan atau norma positif di dalam perundang-undangan yang berlaku. Namun setelah adanya Putusan MK No.69 hukum perkawinan mendapat perubahan terutama mengenai perjanjian kawin dimana perjanjian kawin dapat dibuat selama perkawinan, yang mana isinya berlaku juga terhadap pihak ketiga selama perjanjian itu didaftarkan/dicatatkan sesuai dengan peraturan perundang-undangan yang berlaku.
\end{abstract}

Kata Kunci : Perkawinan Campuran; Perjanjian Kawin; Pihak Ketiga.

\footnotetext{
* Naskah diterima: 27 Juli 2019, direvisi: 21 Agustus 2019, disetujui untuk terbit: 30 September 2019

Doi: $10.3376 /$ jch.v5i1.183
} 


\section{PENDAHULUAN}

Indonesia suatu negara hukum yang telah membuat suatu aturan perkawinan dalam bentuk buku peraturan perundangundangan Tentang Perkawinan (UU No.1 Tahun 1974) beserta peraturan mengenai untuk kelancaran pelaksanaan undangundang perkawinan yaitu PP No 9 Thn 1975 menurut buku undang-undang perkawinan tersebut, yang mana peraturan ini berlaku bagi semua rakyat Indonesia yang berdasarkan Pancasila.

Sebelum berlakunya buku peraturan Undang-Undang tentang Perkawinan (UUP) ketentuan mengenai peraturan perkawinan di atur dalam KUHPer (BW), yang mana peraturan hukum perkawinan masih memperlihatkan hukum dari pemerintahan Hindia Belanda yang mana adanya pergolongan rakyat dan pandangan hukum pada zaman Hindia Belanda. Namun dengan berlakunya buku peraturan perundang-undangan tentang perkawinan No 1 Tahun 1974 (UUP), dimana semua aturan-aturan lain yang tentang perkawinan selama telah di atur dalam undang-undang ini di nyatakan tidak berlaku, seperti mana yang di tuliskan di dalam pasal 66 Undang-Undang Perkawinan (UUP) bahwa untuk perkawinan dan semua sesuatu yang menyangkut dengan perkawinan berdasarkan atas Undang-undang ini, maka dengan berlakunya Undang-undang ini ketentuan-ketentuan yang diatur dalam KUHPer (BW), Ordinansi Perkawinan Indonesia Kristen (Huwelijk Ordanantie Christen Indonesia 1933 No.74), Peraturan Perkawinan Campuran (Regeling op gemeng de Huwelijken S.1898 No.158), dan aturan lain yang mengatur mengenai perkawinan sejauh telah diatur dalam perundang-undangan ini, dinyatakan tidak berlaku.

Menurut kodratnya manusia selalu hidup saling membutuhkan dan individu memiliki jiwa yang menyadari kebutuhan manusia untuk hidup bermasyarakat didasari karena didorong oleh kekuatan biologis yang merupakan kebutuhan seorang manusiawi, seperti keinginan untuk mendapatkan keturunan. Mendapatkan keturunan adalah keinginan dari setiap manusia dimana disitu mereka bisa menemukan kebahagiaan. Dan satusatunya cara yang bisa dilakukan manusia untuk bisa memiliki keturunan adalah dengan membentuk keluarga yang bahagia dan dirahmati oleh Allah SWT, dan hal tersebut dilakukan melalui ikatan perkawinan. Perikatan perkawinan sangat penting dalam pergaulan masyarakat, bahkan hidup bersama ini yang kemudian melahirkan keturunan mereka yang merupakan sendi utama dari pembentukan negara dan bangsa (Laurensius Arliman S, 2015: 289)

Warga Negara Indonesia hidup di masyarakat itu masing-masing mempunyai fungsi pribadi dan fungsi sosial. Dimana nanti kita akan bertemu seseorang dan akan berkeluarga, bertemu dengan pasangan kita, bertemu seseorang dari latar belakang apapun, agama, suku dan bisa beda negara. Tidak bisa terelakkan apabila kita bertemu jodoh kita adalah seorang Warga Negara Asing atau WNA, kemudian jatuh cinta dan memutuskan untuk menikah membentuk suatu keluarga. 
Permasalahan jatuh cinta dengan WNA ini lebih kompleks terutama apabila nanti menikah. Karena bisa berbeda agama, berbeda bahasa, berbeda budaya, berbeda Negara dan berbeda Warga Negara. (Nurmala Ika Widiasari, 2017: 25)

Sejak berlakunya buku peraturan undang-undang Perkawinan (UUP) menerangkan bahwa para pihak yang melakukan ikatan lahir dan batin harus berpedoman kepada buku peraturan Undang-Undang ini dimana sah nya perkawinan terletak di pasal 2 Undangundang Perkawinan ayat(1) dimana sahnya suatu perkawinan apabila dilakukan menurut hukum masing-masing agama dan kepercayaannya itu. Ayat(2) Tiap-tiap perkawinan dicatatkan menurut peraturan perundang-undangan yang berlaku.

Selama belum terdaftar/dicatatkan menurut Undang-undang yang berlaku maka perkawinan tersebut belum bisa dikatakan sah di mata hukum Negara. Perihal tentang pendaftaran/pencatatan perkawinan telah di atur dalam PP Nomor 9 Tahun 1975 tentang Pelaksanaan UU Nomor 1 Tahun 1974 yang mana pendaftaran/pencatatan perkawinan bagi mereka yang beragama islam dapat di daftarkan/dicatatkan di Kantor Urusan Agama (KUA) dan bagi perkawinan mereka selain agama islam dapat juga di daftarkan/dicatatatkan di kantor catatan sipil. Mengenai pendaftaran/pencatatan perkawinan juga tercantum di Undangundang Nomor 23 Tahun 2006 tentang Administrasi Kependudukan yang bertujuan untuk mengatur tata-cara pendaftaran/pencatatan peristiwa penting seperti kelahiran, perkawinan, perceraian, kematian seperti yang tertuang dalam pasal 1 angka 17 Undang-undang Administrasi Kependudukan.

Dengan terpenuhinya syarat-syarat Perkawinan yang cukup akan memberikan kepastian hukum dan kepentingan hukum bagi orang yang melangsungkan perkawinan akan terlindungi. Keanekaragaman budaya dan bahkan negara tidak lagi menjadi hambatan ataupun batasan untuk membentuk suatu hubungan. Hal ini seiringan dengan berkembang nya zaman, teknologi dan pola pikir manusia khususnya masyarakat Indonesia untuk berkomunikasi dan berinteraksi dengan seseorang dari belahan dunia berbeda bukanlah suatu hal yang tabu untuk saat ini. Adanya perkembangan ini, banyak keuntungan yang diperoleh oleh individu, kelompok masyarakat, sehingga bukanlah hal yang mustahil bila ada terjadi perkawinan individu yang mana para pihak memiliki kewarga-negaraan yang berlainan yang di Indonesia biasa dikenal sebagai perkawinan campuran seperti mana yang tercantum di pasal 57 Undang-undang Perkawinan (UUP) Yang dimaksud dengan perkawinan campuran dalam Undang-undang ini ialah perkawinan antara dua orang yang di Indonesia tunduk pada hukum yang berlainan, karena perbedaan kewarganegaraan dan salah satu pihak berkewarganegaraan Indonesia.

Apabila para pihak melakukan perkawinan di luar Indonesia maka perkawinan tersebut dapat dikatakan sah bilamana perkawinan tersebut menurut 
hukum Negara yang berlaku menurut di Negara mana perkawinan tersebut di langsungkan dan di haruskan selambatlambat nya 1 (satu) tahun setelah kembali ke Indonesia harus segera di daftarkan/dicatatkan oleh pegawai pencatatan perkawinan dimana tempat mereka tinggal agar tidak melanggar Undang-undang dan hukum di Indonesia.

Dalam Undang-undang Perkawinan (UUP), konsep perkawinan campuran hanya menekankan pada perbedaan kewarganegaraan, dan salah satunya harus kewarganegaraan Indonesia. Dalam perkawinan campuran karena adanya perbedaan kewarga-negaraan dari suami atau istri maka pihak istri mempunyai pilihan, yaitu mengikuti status kewarganegaraan dari suami atau istrinya untuk memperoleh kesatuan hukum dalam perkawinan atau tetap mengikuti kewarganegaraan nya semula dengan mempertahankan kewarga-negaraan Indonesia dengan berpedoman dengan aturan yang ada dalam Undang-undang.

Berdasarkan UU No 12 Tahun 2006 tentang Kewarganegaraan di mana yang disebut Kewarganegaraan adalah suatu warga Negara yang menurut perundangundangan/hukum secara resmi merupakan warga yang sah dari Negara tersebut. Perkawinan campuran di laksanakan di Indonesia yang berpedoman pada Undangundang yang berlaku di mana kewarganegaraan di dapat karena perihal perkawinan atau putusnya perkawinan yang menentukan adalah hukum yang berlaku baik hukum publik ataupun hukum perdata. Mengenai untuk tata-cara perkawinan campuran harus dipenuhi syarat-syarat perkawinan materil yang berlaku menurut hukum masing-masing pihak dimana perkawinan campuran tidak boleh di lakukan apabila belum bisa membuktikan/menunjukkan bahwa syarat perkawinan yang di tentukan oleh masingmasing pihak dipenuhi dan di berikan surat keterangan bahwa syarat-syarat sudah terpenuhi.

Apa bila pejabat bersangkutan menolak surat keterangan tersebut dikarenakan ada nya persyaratan yang belum terpenuhi maka para pihak yang mengajukan perkawinan tidak boleh di mintakan banding tentang penolakan tersebut seperti mana yang di sebutkan dalam pasal 60 Undang-undang Perkawinan bahwa :

1) Perkawinan campuran tidak dapat dilaksanakan sebelum terbukti bahwa syarat-syarat perkawinan yang di tentukan oleh pihak masing-masing telah dipenuhi.

2) Untuk membuktikan bahwa syarat-syarat tersebut dalam ayat (1) telah dipenuhi dank arena itu tidak ada rintangan untuk melangsungkan perkawinan campuran maka oleh mereka yang menurut hukum yang berlaku bagi pihak masing-masing berwenang mencatat perkawinan, diberikan surat keterangan bahwa syarat-syarat telah dipenuhi

3) Jika pejabat yang bersangkutan menolak untuk memberikan surat keterangan itu, maka atas permintaan yang berkepentingan, Pengadilan memberikan keputusan dengan tidak beracara serta tidak boleh diminta banding lagi tentang soal apakah penolakan pemberian surat 
keterangan itu beralasan atau tidak.

4) Jika Pengadilan memutuskan bahwa penolakan tidak beralasan, maka keputusan itu menjadi pengganti keterangan tersbut ayat(3).

5) Surat keterangan atau putusan pengganti keterangan tidak mempunyai kekuatan lagi jika perkawinan itu tidak dilangsungkan dalam masa 6 (enam) bulan sesudah keterangan itu diberikan.

Menurut UU No 12 Tahun 2006 tentang Kewarganegaraan bagi suami-istri dalam perkawinan campuran khusus nya bagi Warga Indonesia yang masih mempertahankan kewarganegaraannya dapat mengajukan surat pernyataan kepada pejabat yang telah di tunjuk oleh Undangundang karena status kewarga-negaraan sangat lah penting, yang mana hal ini berkaitan terhadap hukum yang akan berlaku padanya dan juga kedudukan sebagai subjek pemegang hak atas tanah.

Mengingat dengan berlakunya peraturan perundang-undangan tentang Kewarganegaraan ini tentu saja membawa konsekuensi-konsekuensi yang di timbulkan, seperti dalam ikatan perkawinan campuran yang mana menurut Undang-undang Perkawinan (UUP) bahwa harta benda yang diperoleh selama perkawinan menjadi harta bersama di karenakan pembulatan harta bersama di mana di dalam nya terdapat sebahagiannya harta Warga Asing (WNA) selama mereka tidak mengatur lain mengenai harta benda dengan membuat perjanjian kawin.

Mengenai kewenangan bertindak terhadap harta semasa suami dan isteri masih dalam status perkawinan yaitu terhadap harta bersama, masing-masing isteri atau suami bertindak dengan persetujuan pihak lainnya, bahkan apabila para pihak bercerai hidup maka harta bersama dibagi sesuai dengan hukumnya masing-masing yang umum nya dibagi dua sama besar.

Berhubungan dengan Undang-Undang Perkawinan tentang harta bersama setelah. Perkawinan kedudukan para pihak dianggap sama atau seimbang. Dengan demikian suami-istri dalam perkawinan campuran juga menyebabkan terjadinya percampuran harta para pihak oleh karenanya Warga Indonesia (WNI) yang melakukan perkawinan campuran tanpa adanya perjanjian kawin pisah harta kehilangan hak nya untuk melakukan perbuatan hukum khususnya untuk memiliki/memperoleh hak tanah di Indonesia karena akan menjadi bahagian dari harta bersama dengan Warga Asing (WNA), ini menyangkut dengan kepemilikan tanah yang mana Undangundang pertanahan di Indonesia menganut asas Nasionalisme yang menegaskan bahwa Warga Negara Asing tidak diperbolehkan untuk memiliki hak atas tanah di Indonesia.

Suatu perbuatan hukum yang dilakukan dalam perkawinan yang sah dimana para pihak yang melakukannya telah ditentukan oleh hukum dan terhadapnya akan menimbulkan suatu akibat hukum bagi para pihak tersebut. Perbuatan hukum yang demikian itu akan melahirkan hak dan kewajiban bagi para pihak yang telah berjanji mengikat diri 
satu sama lainnya secara lahir dan bathin oleh karenanya akan menimbulkan akibat hukum bagi kedua belah pihak tersebut. (Ahmad Rofiq, 2003:17)

Peraturan yang mengatur pertanahan di muat dalam UU Nomor 5 Tahun 1960, yang di kenal dengan Undang-undang Pokok Agraria (UUPA) yang mana undang-undang ini menganut asa Nasionalisme, dengan kata lain bahwa hanya warga Negara Indonesia yang dapat untuk memiliki hak atas tanah.

Di sini timbul suatu permasalahan dimana para pihak perkawinan campuran tanpa adanya perjanjian kawin kehilangan hak nya sebagai warga-negara untuk memiliki hak atas tanah di karenakan pembulatan harta bersama selama perkawinan, di samping itu mengenai perjanjian kawin yang di atur dalam Undang-undang Perkawinan yang mana perjanjian kawin di buat pada waktu atau sebelum perkawinan dilangsungkan, seperti mana yang tertulis pada pasal 29 Undang-undang Perkawinan :

1) Pada waktu atau sebelum perkawinan dilangsungkan kedua belah pihak atas persetujuan bersama dapat mengajukan perjanjian tertulis yang disahkan oleh pegawai pencatatan perkawinan setelah mana isinya berlaku juga terhadap pihak ketiga

2) Perkawinan tersebut tidak dapat disahkan bilamana melanggar batas-batas hukum, agama dan kesusilaan.

3) Perjanjian tersebut dimulai berlaku sejak perkawinan dilangsungkan.

4) Selama perkawinan dilangsungkan perjanjian tersebut tidak dapat diubah, kecuali bila dari kedua belah pihak ada persetujuan untuk mengubah dan perubahan tidak merugikan pihak ketiga.

Dari pasal tersebut bagi pasangan suami-istri diberi kesempatan apabila mereka memutuskan untuk menentukan lain, dengan kata lain mengadakan penyimpangan dari peraturan yang ada dalam undang-undang, yang mana penyimpangan tersebut terkait dengan harta perkawinan hanya dapat dilakukan dengan cara membuat perjanjian kawin yang di buat pada waktu atau sebelum perkawinan dilangsungkan.

Perkawinan campuran antara Warga Negara Indonesia dengan Warga Negara Asing adalah konsekuensi logis dari perkembangan jaman serta pesatnya perkembangan wisatawan yang datang ke Indonesia. Peristiwa perkawinan campuran yang demikian itu bukan saja merupakan suatu perbuatan hukum yang menimbulkan suatu permasalahan dan mempunyai akibat hukum yang bersifat keperdataan, akan tetapi juga menimbulkan permasalahan dan akibat hukum publik, terutama di bidang kewarganegaraan. (Fauzi, 2018) Perkawinan campuran di Indonesia sangatlah di perhatikan karena di saat Warga Negara Indonesia melakukan perkawinan campuran dimana dia mempertahankan kewarganegaraannya dan haknya sebagai warga-negara hilang untuk dapat memiliki haknya atas tanah di Indonesia.

Perbedaan yang dirasakan oleh suamiistri dalam perkawinan campuran 
membuat untuk mengajukan permohonan pengujian undang-undang yang menghalangi para pihak perkawinan campuran tanpa ada nya perjanjian kawin ke Mahkamah Konstitusi. Dan pada akhirnya permohonan pengujian atas undang-undang ini telah memperoleh Putusan dari Makamah Konstitusi (MK) Nomor 69/PUU-XIII/2015, dimana dalam putusan ini menyatakan bahwa perjanjian kawin dapat juga di lakukan setelah perkawinan dilangsungkan.

Namun apakah dengan putusan Mahkamah Konstitusi ini telah membawa dampak yang sebagaimana di inginkan oleh para pihak dalam perkawinan campuran untuk melindungi haknya sebagai warga-negara dalam memperoleh hak atas tanah tanpa adanya perbedaan lagi.

Berdasarkan latar belakang tersebut
sangat menarik untuk diteliti permasalahannya antara lain: Apakah para pihak dalam perkawinan campuran mendapat halangan untuk memiliki hak atas tanah di Indonesia ? Dan Apakah akibat hukum dari perjanjian kawin yang dibuat setelah perkawinan bagi para pihak?

Tulisan ini bertujuan agar para pihak dalam perkawinan campuran mengetahui apa saja peraturan-peraturan yang berlaku saat ini agar tidak menghambat para pihak untuk memiliki hak atas tanah di Indonesia dan agar para pihak mengetahui pihakpihak mana saja yang terbawa dalam perjanjian perkawinan ini.

\section{METODE PENELITIAN}

Metode penelitian tulisan ini menitik beratkan ke metode pendekatan yuridis normatif dengan mengkaji atau menganalisa bahan pustaka dan peraturan perundang-undangan, serta perlindungan hukum yang harus dilakukan bagi warga Negara agar tidak kehilangan hak nya sebagai warga Negara serta menggunakan data sekunder meliputi bahan hukum sekunder dan bahan hukum tersier. Untuk menyatakan bahwa nilai ilmiah suatu pembahasan dan pemecahan masalah terhadap legal issue yang diteliti sangat tergantung kepada cara pendekatan yang digunakan.

\section{HASIL DAN PEMBAHASAN}

\section{Faktor Penghalang Kepemilikan Hak Atas Tanah Dalam Perkawinan Campuran}

Seiring perkembangan zaman perkawinan campuran di Indonesia bukanlah menjadi hal yang tabu di mana banyak nya para pihak perkawinan campuran telah mendapat perlindungan hukum yang telah di akomodir dengan baik dalam perundang-undangan. Di mana perkawinan ini dapat dilakukan di luar Indonesia (luar negeri) dan dapat pula dilangsungkan di Indonesia seperti yang tercatat di pasal 56 Undang-undang Perkawinan menyatakan bahwa :

1) Perkawinan di Indonesia antara dua orang warga-negara Indonesia atau seorang warganegara Indonesia dengan warganegara asing adalah sah bilamana dilakukan menurut hukum yang berlaku di Negara dimana perkawinan itu dilangsungkan dan 
bagi warga-negara Indonesia tidak melanggar ketentuan Undang-undang ini.

2) Dalam waktu 1 (satu) tahun setelah suami-istri itu kembali di wilayah Indonesia, surat bukti perkawinan mereka harus didaftarkan di kantor Pencatat perkawinan tempat mereka tinggal.

Perkawinan campuran yang di laksanakan di Indonesia harus berpedoman pada Undang-undang Perkawinan yang berlaku saat ini. Perkawinan campuran tanpa adanya perjanjian kawin sungguh sangat menghambat untuk dapat memiliki hak atas tanah selama perkawinannya di karenakan pembulatan harta bersama yang mana di dalam harta bersama termasuk harta warga Negara asing.

Harta benda yang dihasilkan selama perkawinan akan menjadi harta bersama suami-istri dengan kata lain bahwa konsep harta bersama yang merupakan harta kekayaan yang dapat ditinjau dari segi ekonomi dan dari segi hukum, walaupun kedua segi di tinjau dari segi ekonomi berbeda, namun keduanya ada hubungan satu sama lainnya. (Abdul Kadir Muhammad. A, 2000: 71)

Seperti mana yang telah ditegaskan dalam peraturan perundang-undangan mengenai pertanahan atau agraria bahwa warga Negara asing tidak boleh melakukan perbuatan hukum khusus nya jual/beli berupa apapun terutama tanah dan bangunan baik secara langsung ataupun tidak langsung dengan bermaksud untuk memindahkan hak atas tanah kepada orang asing.
Salah satu persoalan yang timbul karena adanya harta bersama terjadi ketika objek harta bersama tersebut merupakan tanah yang dimiliki oleh WNI, baik posisinya sebagai suami ataupun istri. Hal tersebut dikarenakan tanah tidak dapat dimiliki oleh orang asing, baik statusnya berkedudukan di Indonesia ataupun tidak. Tidak dapat dimiliki dalam hal ini merupakan hak penguasaan atas tanah yang di dasari oleh Hak Milik. Ketentuan ini merupakan konsekuensi dengan adanya Hak Bangsa yang merupakan hak penguasaan tanah tertinggi yang menempatkan seluruh bangsa Indonesia sebagai pemiliknya. Ketentuan terebut juga diperkuat dengan Pasal 9 ayat (1) UUPA yang mengatur hanya WNI dapat mempunyai hubungan yang sepenuhnya dengan bumi, air, ruang angkasa dan seluruh kekayaan alam yang ada di Indonesia. Ketentuan tersebut selanjutnya dipertegas oleh Pasal 21 ayat (1) UUPA yang menegaskan hanya WNI yang dapat mempunyai Hak Milik. (Eddy Nyoman Winarta, 2017: 51)

Seperti yang dirasakan oleh Nyonya Ike Farida, yang menikah dengan seorang berkewarganegaraan Jepang. Saat pembelian sebuah rumah susun di Jakarta, setelah adanya pembayaran lunas atas rumah susun tersebut tapi tidak kunjung diserahkan. Bahkan kemudian perjanjian pembelian dibatalkan secara sepihak oleh pengembang dengan alasan suami merupakan Warga Negara Asing (WNA) dan tidak memiliki perjanjian perkawinan.

Pembatalan ini oleh pengembang, didasarkan atas Pasal 36 ayat (1) UUPA 
dan Pasal 35 ayat (1) UUP. Berdasarkan kedua pasal tersebut, pihak pengembang menyimpulkan bahwa apabila seorang suami atau isteri membeli benda tidak bergerak (dalam hal ini adalah rumah susun/apartemen) sepanjang perkawinan maka apartemen tersebut akan menjadi harta bersama suami isteri yang bersangkutan. Termasuk juga jika perkawinan tersebut adalah perkawinan campuran (perkawinan antara seorang Warga Negara Indonesia (WNI) dengan seorang Warga Negara Asing (WNA) yang dilangsungkan tanpa membuat perjanjian kawin harta terpisah, maka demi hukum apartemen yang dibeli oleh seorang suami/isteri Warga Negara Indonesia (WNI) dengan sendirinya menjadi milik suami/isteri yang Warga Negara Asing (WNA) juga. Penolakan pembelian dari pengembang ini, kemudian dikuatkan oleh Pengadilan Negeri Jakarta Timur melalui Penetapan

Nomor 04/CONS/2014/PN.JKT.Tim.

Hambatan yang dirasakan para pihak dalam perkawinan campuran tanpa adanya perjanjian kawin ini sangat menghalangi warga-negara Indonesia untuk melakukan perbuatan hukum khusus nya untuk memiliki hak atas tanah di wilayah Indonesia. Akhirnya para pihak perkawinan campuran mengajukan permohonan pengujian atas undangundang yang menghambat para pihak perkawinan campuran untuk memiliki tanah ke Mahkamah Konstitusi (MK).

Atas pengujian ini Mahkamah Konstitusi memberi putusan atas permohonan para pihak dalam perkawinan campuran dalam putusan Nomor 69/PUUXIII/2015, di mana yang awalnya perjanjian kawin hanya dapat dibuat pada waktu atau sebelum perkawinan akhirnya dapat di buat setelah atau selama perkawinan berlangsung dan perjanjian tersebut harus segera di sahkan oleh pegawai pencatat perkawinan di mana isi dari perjanjian tersebut berlaku terhapat pihak ketiga selama pihak ketiga terlihat atas perbuatan hukum yang di lakukan par pihak perkawinan campuran dalam perjanjian kawin yang di buat.

Disadari dengan keluarnya putusan Nomor 69/PUU-XIII/2015 oleh Mahkamah Konstitusi (MK) hukum perkawinan di Indonesia mendapat perubahan yang besar dalam perkawinan campuran untuk dapat melakukan perbuatan hukum khusus nya kepemilikan atas tanah di Indonesia. Atas keluarnya keputusan tersebut Mahkamah Konstitusi berperan penuh untuk menjamin perlindungan hak asasi manusia, karena menegakkan hak-hak asasi manusia dan hak-hak konstitusional warga negara adalah bagian dari penegakan konstitusi itu sendiri serta memberi perlindungan hukum bagi para pihak perkawinan campuran.

Isi Perjanjian perkawinan diserahkan pada pihak calon pasangan yang akan melangsungkan perkawinan dengan dasar asas kebebasan berkontrak syarat isinya tidak boleh bertentangan dengan ketertiban umum, kesusilaan, hukum dan agama, perjanjian perkawinan sebelum perkawinan dibuat berdasarkan kesepakatan. Dalam Pasal 29 ayat 2 Undang-Undang Nomor 1 Tahun 1974 
Jurnal Cendekia Hukum: Vol. 5, No 1, September 2019

tentang Perkawinan memuat tentang batasan-batasan isi dalam perjanjian perkawinan, disitu terjadi kekaburan hukum karena tidak menjelaskan dengan rinci tentang apa saja yang dapat diatur sebagai isi perjanjian perkawinan, tetapi hanya memberi batas-batas hukum, agama dan kesusilaan dalam membuat perjanjian perkawinan yang tidak boleh dilanggar, sehingga kedua belah pihak bebas dalam menentukan isi perjanjian dengan mengacu pada asas kebebasan berkontrak, kadang menimbulkan ketimpangan apabila salah satu pihak berada dalam suatu keadaan yang dominan. Dampak positif yang dapat ditimbulkan sebagai suatu bentuk perlindungan terhadap wanita pelaku pernikahan campuran dan anakanak dalam hal kepemilikan atas tanah di Indonesia. (Aislie Anantama Septiawan, 2017:66)

Adapun syarat pembuatan perjanjian perkawinan tersebut sama halnya dengan perjanjian-perjanjian seperti biasanya yang mana perjanjian haruslah didasarkan pada pembuatan perjanjian sebagaimana mestinya berdasarkan pada asas-asas kebebasan berkontrak, asas kekuatan mengikat, asas kepercayaan, dan asas itikad baik.

Perjanjian kawin tersebut juga harus di daftarkan/dicatatkan, bagi yang beragama islam pendaftaran/pencatatan dilakukan di Kantor Urusan Agama dan bagi selain beragama islam dapat didaftarkan/dicatatkan oleh kantor catatan sipil setempat.

Akta catatan sipil merupakan suatu hal yang sangat penting dan perlu karena dengan akta catatan sipil orang dapat dengan mudah memperoleh kapasitas akan kejadian-kejadian seperti kelahiran, kematian, perkawinan, perceraian, pengakuan anak, pengesahan anak dan pergantian nama. Hal ini sesuai dengan tujuan dari lembaga catatan sipil itu sendiri yaitu suatu lembaga yang memberikan kepastian hukum yang sebesar-besarnya, selengkap-lengkapnya serta sejelasjelasnya akan kejadian atau peristiwa atau kejadian sendiri maupun orang lain yang berkepentingan mempunyai bukti atau kepastian hukum tentang peristiwa atau kejadian tersebut. Catatan sipil mengandung arti suatu lembaga yang ditugaskan untuk memelihara daftar-daftar atau catatancatatan guna pembuktian status atau peristiwa-peristiwa penting bagi warga negara, atau dapat pula dikatakan bahwa lembaga catatan sipil adalah suatu lembaga atau badan pemerintah yang ditugaskan mencatat dalam suatu daftar tertentu peristiwa-peristiwa yang mempunyai arti penting bagi status keperdataan seperti kelahiran, kematian, perkawinan, pengakuan anak, pengesahan anak, perceraian dengan maksud untuk dipergunakan sebagai pembuktian tentang adanya atau telah terjadinya peristiwaperistiwa tersebut.

Ketentuan mengenai proses sahnya perjanjian perkawinan yang berpodoman dengan undang-undang yang berlaku tidak hanya diperuntukkan bagi perkawinan campuran saja melainkan kepada semua perkawinan secara umum. Dimana dengan adanya putusan Mahkamah Konstitusi ini memberi kesempatan bagi para pihak dalam perkawinan untuk mengajukan 
perjanjian kawin selama masa perkawinan yang bertujuan agar mendapatkan haknya sebagai warga-negara untuk memiliki tanah di Indonesia.

Banyak opini dari masyarakat yang beranggapan apa bila ada pasangan suamiistri memutuskan untuk membuat suatu perjanjian perkawinan, maka mereka mempersiapkan untuk perceraian. Terlepas dari anggapan miring dari masyarakat seperti itu, maksud baik nya dapat diambil bahwa para pihak perkawinan bermaksud dibuatnya perjanjian kawin dimana perjanjian kawin memberikan perlindungan hukum bagi suami dan istri yang akan terikat dalam suatu perkawinan menyangkut prihal harta-benda selama perkawinan terutama bagi para pihak perkawinan campuran dimana para pihak dalam perkawinan campuran yang mempertahankan kewarga-negaraannya agar tidak kehilangan haknya untuk memiliki tanah di Indonesia.

\section{Akibat Hukum Dari Perjanjian Perkawinan Bagi Pihak Ketiga}

Perjanjian perkawinan pasca putusan Mahkamah Konstitusi Nomor 69/PUUXIII/2015 tentang perkawinan adalah suatu perbuatan hukum yang dapat dibuat pada waktu atau selama perkawinan atas persetujuan bersama antara suami dan istri yang mana perjanjian tersebut sebaiknya dituangkan kedalam akta yang disahkan oleh pejabat umum (notaris) dan perjanjian tersebut harus juga di daftarkan/dicatatkan yang mana isinya berlaku juga bagi pihak ketiga selama pihak ketiga tersebut tersangkut agar mendapat perlindungan hukum atas perjanjian perkawinan yang di buat tersebut, dengan terpenuhinya syaratsyarat perjanjian kawin sesuai dengan perundang-undangan yang berlaku bahwa pencatatan perjanjian kawin bertujuan untuk mempublikasikan agar perjanjian tersebut dapat mengikat semua pihak yang terkait termasuk juga menyangkut pihak ketiga.

Konsep pemisahan harta dalam perjanjian kawin telah sesuai dengan maslahah mursalah, dimana pada konsep pemisahan harta merupakan bentuk dari perlindungan terhadap jiwa dan harta pasangan suami-istri. (Dyah Ochtorina Susanti, 2018:82).

Setelah isi perjanjian yang diajukan oleh pihak-pihak tertuang dalam akta notaris, maka surat tersebut menjadi surat otentik yang memiliki kekuatan pembuktian sempurna dalam suatu perkara dan menjadi undang-undang bagi para pihak. Atas dasar kewenangan yang diberikan oleh Undang-Undang kepada notaris, maka Notaris dapat menjamin dan menyimpan akte yang dibuat tersebut juga terdapat aneka ragam pembuktiannya, misalnya kekuatan dalam pembuktian bahwa seseorang telah atau melakukan perbuatan hukum (misal: wasiat, hibah dan sebagainya), kekuatan eksekusi (misal: akte hipotek) memiliki kekuatan lainnya dalam rangka konteks hukum. (Rahmawati Boty, 2017:86)

Ketentuan mengenai isi perjanjian kawin yang hanya didaftarkan di Pengadilan Negeri sejak diundangkannya Undang-Undang Perkawinan hanya berlaku secara intern antara suami dan isteri. Perjanjian kawin yang telah 
Jurnal Cendekia Hukum: Vol. 5, No 1, September 2019

dicatatkan pada Pegawai Pencatat Perkawinan berpengaruh terhadap daya ikat atas perjanjian kawin tersebut kepada pihak ketiga. Dengan demikian isi perjanjian kawin selain mengikat para pihak yang membuatnya juga mengikat pihak ketiga yang tersangkut dengan para pihak. (Dian Trisna Dewi, 2018: 39)

Ketentuan mengenai perjanjian kawin yang didaftarkan/dicatatkan sesuai dengan aturan perundang-undangan yang berlaku sangatlah berpengaruh terhadap daya ikat atas perjanjian kawin tersebut kepada pihak ketiga. Dengan demikian isi perjanjian kawin selain mengikat suamiistri juga mengikat pihak ketiga yang tersangkut dengan si pembuat perjanjian. Pada umum nya pihak ketiga itu adalah mereka yang tidak untuk dirinya sendiri atau berdasarkan atas perwakilan, baik perwakilan dikarenakan oleh undangundang maupun perwakilan dikarenakan suatu perjanjian, atau melakukan suatu perjanjian. Yang mereka yang digolongkan ke dalam kategori pihak ketiga ini sangat luas dan bergantung pada pebuatan hukum nya dengan para pihak dari suatu perjanjian.

Suatu perjanjian khusus nya perjanjian kawin yang sah menurut UU berlaku juga terhadap pihak ketiga atau harus dihormati juga oleh pihak ketiga, yang berisikan tentang hal yang dianggap penting oleh para pihak yang belum diatur dalam UU atau bahkan terhadap hal-hal yang menjadi penyimpangan dari ketentuan UU sepanjang dibolehkan oleh UU, agama dan kesusilaan seperti perjanjian tentang kedudukan anak atau harta benda selama perkawinan bahkan setelah putusnya perkawinan. (Munir Fuady, 2014:18)

Di dalam pasal 12 PP Nomor 9 Tahun 1975 tentang Pelaksanaan Undang-Undang Nomor 1 Tahun 1974 Tentang Perkawinan, juga menyebutkan bahwa perjanjian perkawinan harus tercantum di dalam akta perkawinan. Maka walaupun perjanjian perkawinan itu ada dan di buat oleh suami istri tetapi karena tidak di sahkan oleh Pegawai Pencatat Perkawinan maka perjanjian tersebut tidak termuat di dalam akta perkawinan. Sehingga apabila terjadi masalah terkait pihak ketiga maka perjanjian perkawinan tersebut di anggap tidak ada dan tidak mengikat pihak ketiga. (Erdhyan Paramitha, 2017:37)

Namun bagi suami isteri yang telah membikin suatu perjanjian kawin, hutang yang terjadi selama perkawinan berlangsung hanya menjadi tanggung jawab salah satu pihak yang hendak melakukan perbuatan hukum saja, sedangkan salah satu pihak tidak terikat daripadanya dan tidak memiliki kewajiban dan tanggung jawab untuk ikut membayar terhadap hutang pasangannya. Sama halnya dimana perkawinan campuran dengan membuat perjanjian kawin setelah perkawinan sesuai dengan ketentuan yang berlaku akan membawa akibat hukum terutama terhadap pihak ketiga yaitu dalam melakukan perbuatan hukum pihak ketiga hanya terkait dengan harta salah satu pihak dari suami atau pun isteri berkewarganegaraan Indonesia yang melakukan perbuatan hukum tanpa melibatkan harta pasangannya, sehingga Warga Negara Indonesia (WNI) dapat 
melakukan perbuatan hukum tanpa melibatkan harta pasangannya yang berkewarganegaraan asing.

\section{SIMPULAN}

1. Sebagai mana yang disebutkan dalam pasal 29 UUP bahwasannya perjanjian kawin dapat dibuat pada waktu dan sebelum perkawinan dimana para pihak yang melakukan perkawinan campuran tanpa adanya perjanjian kawin mendapat hambatan untuk memiliki tanah di Indonesia dikarenakan pembulatan harta bersama setelah perkawinan dengan warga asing, dimana UU mengenai pertanahan di Indonesia menganut asas Nasionalisme yang mengutamakan hanya warga-negara Indonesia saja yang dapat memperoleh hak atas tanah. Namun setelah adanya Putusan MK No 69 suami-istri dalam perkawinan campuran tanpa adanya perjanjian kawin mendapat kesempatan untuk mengajukan perjanjian kawin selama perkawinan berjalan dan putusan ini bukan hanya berlaku bagi perkawinan campuran namun berlaku juga bagi semua perkawinan di Indonesia.

2. Perjanjian perkawinan yang dibuat pasca putusan MK No.69 membawa akibat terhadap status hukum harta benda yang didapat atau diperoleh selama perkawinan. Bagi pihak ketiga sangatlah penting untuk mengetahui bagaimana kedudukan harta kekayaan suami-istri apalagi dalam perkawinan campuran dimana perkawinan tersebut dilakukan oleh dua orang yang tunduk pada hukum yang berlainan dikarenakan perbedaan kewarganegaraan dan salah satu pihak berkewarganegaraan Indonesia agar mendapatkan haknya untuk bisa memiliki tanah di Indonesia. Dengan demikian dalam pembuatan perjanjian kawin berlaku juga bagi pihak ketiga selama perjanjian tersebut didaftarkan/dicatatkan yang sesuai ketentuan perundang-undangan dan selama perkawinan perjanjian tersebut tidak dapat dirubah kecuali ada persetujuan dari kedua belah pihak dan perubahan itu tidak merugikan pihak ketiga.

Berkaitan dari simpulan penulis dapat memberikan saran bagi para pihak yang melakukan perkawinan campuran sebaiknya membuat perjanjian kawin dalam bentuk akta otentik yang dibuat oleh pejabat umum (Notaris) dan di catatkan oleh pegawai pencatat perkawinan agar mendapat kepastian hukum dan tidak mendapat hambatan untuk mendapatkan haknya sebagai Warga-negara Indonesia terutama dalam melakukan perbuatan hukum untuk memiliki tanah di Indonesia.

\section{UCAPAN TERIMAKASIH}

Puji dan Syukur penulis ucapkan ke hadirat Allah SWT yang telah memberikan Rahmat dan Karunia-Nya, sehingga akhirnya penulis dapat menyelesaikan penulisan karya ilmiah ini dimana penulis menyadari dukungan dari para pihak yang mendukung sehingga karya ilmiah ini terselesaikan, dengan kerendahan hati penulis mengucapkan terimakasih sedalam-dalamnya kepada : 
1. Dr. Yoan Nursari Simanjuntak, S.H., M.Hum. Selaku Dekan Fakultas Hukum Universitas Surabaya (UBAYA)

2. Dr. Wisnu Aryo Dewantoro, S.H., LL.M., LL.M. Selaku perwakilan dosen Fakultas Hukum Universitas Surabaya (UBAYA).

3. Beserta seluruh keluarga dan kerabat yang mendo'a kan demi kelancaran semuanya.

\section{DAFTAR PUSTAKA}

\section{Buku-Buku}

Abdul Kadir Muhammad. A, 2000, Hukum Perdata Indonesia, Citra Aditya Bakti, Bandung.

Munir Fuady, 2014, Konsep Hukum Perdata, Raja Grafindo Persada, Jakarta.

Ahmad Rofiq, 2003, Hukum Islam Di Indonesia, Raja Grafindo Persada, Jakarta.

\section{Jurnal}

Nurmala Ika Widiasari, 2017. "Tijauan Yuridis Tentang Perolehan Hak Atas Tanah Bagi Peremuan WNI Yang Terikat Perkawinan Campuran." Jurnal Akta 4(1):25.

Laurensius Arliman S, 2019. "Peran Lembaga Catatan Sipil Terhadap Perkawinan Campuran Berdasarkan Undang-Undang Perkawinan." JCH (Jurnal Cendikia Hukum) 4(2):289.

Eddy Nyoman Winarta, 2017. "Hak Pakai Atas Rumah Hunian Warga Negara Asing Dalam Perkawinan Campuran Tanpa Perjanjian Kawin." Acta Comitas 2(1):51.

Dyah Ochtorina Susanti, 2018. "Mengurai Konsep Pemisahan Harta Setelah
Perkawinan : Perspektif Maslahah Mursalah." Arena Hukum 11(1):82

Aislie Anantama Septiawan, 2017. "Perjanjian Perkawinan Pada Perkawinan Campuran Dalam Kepemilikan Tanah Di Indonesia." Lam Laj 2(1):66.

Rahmawati Boty, 2017. "Kekuatan Akta Notaris Dalam Menjamin Hak Keperdataan." JCH (Jurnal Cendikia Hukum) 3(1):86.

Erdhyan Paramitra, 2017. "Akibat Hukum Perjanjian Perkawinan Yang Tidak Di Sahkan Oleh Pegawai Pencatat Perkawinan." Jurnal Repertorium 4(2):37.

Dian Trisna Dewi, 2018. “Akibat Hukum Pendaftaran Perjanjian Kawin Terhadap Pihak Ketiga Menurut Hukum Positif, 2018. “ Jurnal Hukum Dan Kenotariatan 2(2):39.

Fauzi, R. (2018). Dampak Perkawinan Campuran Terhadap Status Kewarganegaraan Anak Menurut Hukum Positif Indonesia. Soumatera Law Review, 1(1), 153.

\section{Undang-Undang}

Undang-Undang Nomor 1 Tahun 1974 Tentang Perkawinan

Undang-Undang Nomor 5 Tahun 1960 Tentang Peratuan Dasar Pokok Pokok Agraria (UUPA)

Undang-Undang Nomor 12 Tahun 2006 Tentang Kewarganegaraan 